Abbreviated Key Title: Sch J Agric Vet Sci

ISSN 2348-8883 (Print) | ISSN 2348-1854 (Online)

Journal homepage: https://saspublishers.com/sjavs/

\title{
Ethnomedicinal Treatment for Blindness in Bovine
}

Umakanthan $\mathrm{T}^{1^{*}}$, Madhu Mathi $\mathrm{P}^{2}$, Umadevi $\mathrm{U}^{3}$

${ }^{1}$ Veterinary Surgeon, Durairajapuram Colony, Anaikaraipatty (Post), Bodinayakanur (Taluk), Theni (Dt.), Tamil Nadu, India

${ }^{2}$ Veterinary Surgeon, Vadakupudhu palayam, Kodumudi (Taluk), Erode (Dt), Tamilnadu, India

${ }^{3}$ Assistant Professor, Department of Botany, the Standard Fireworks Rajaratnam College for Women, Sivakasi, Virudhunagar (Dt), Tamil Nadu, India

DOI: $10.36347 /$ sjavs.2020.v07i08.006

| Received: 13.08.2020 | Accepted: 20.08.2020 | Published: 30.08.2020

*Corresponding author: Umakanthan $\mathrm{T}$

Abstract

Original Research Article

Thirty bovine cases of blindness due to variousetiologiesare studied giving ethno-medicinal therapy. Clinical examination of the presented cases revealed partial to complete lack of vision, of which some are known affected with listeriosis. Group A of 4 animals given no treatment. Group B of 4 animals were treated with vitamin A and multivitamin injections daily. Both groups recorded no improvement in vision. Group $\mathrm{C}$ of 26 animals were sublingually applied the fine-ground paste made of Datura inoxia, Acoruscalamus, Allium sativum, common salt and cow butter, for 7 to 15 days once daily. Eventually recovery recorded in 20 animals of group $\mathrm{C}$ and thus the effectivity was found to be $92 \%$.

Keywords: Bovine, blindness, vitamins, alternative medicine treatment.

Copyright @ 2020: This is an open-access article distributed under the terms of the Creative Commons Attribution license which permits unrestricted use, distribution, and reproduction in any medium for non-commercial use (NonCommercial, or CC-BY-NC) provided the original author and source are credited.

\section{INTRODUCTION}

Blindness, inability to see, is a common condition which poses major problem in domestic animals, especially cattle. Even after a successful specific therapy for a specific disease which has blindness as one of the symptoms, the blindness usually not responding but persists. Though the disease/causative-specific treatment is given and the animal got to recover, blindness can still persist. It hugely defers the value of the animal. Thus an effective field applicable treatment using ethno-medicinal formulation was tried and presented in this paper.

\section{MATERIAL AND METHOD}

Thirty four cases of blindness were studied, including listeriosis. The animals were presented for unsteady walk, striking upon walls, problem following the owner and feeding, along with the disease-specific other symptoms. Clinical examination revealed wobbling gait, and mere absence of menace, palpebral reflex and corneal reflex, with conjunctivitis in some cases. Treatment method for such partial to complete blindness was tried as below.

Group A of 4 cattle kept as control with no treatment.Group B of 4 cattle were given recommended dose of Advel-A (vitamin A-Morvel laboratories) and multi-vitamin injections daily for 15 days.
Group C of 26 cattle were sublingually applied with the finely ground paste consisting of Datura inoxia(downy thorn-apple) 10gm, Acoruscalamus(sweet flag) $10 \mathrm{gm}$, Allium sativum (garlic) $10 \mathrm{gm}$, common salt $10 \mathrm{gm}$ and cow butter $10 \mathrm{gm}$, for 7 to 15 days once daily.

\section{RESULT AND DISCUSSION}

No sign of improvement in vision noticed in group A. One animal of group B and 20 animals of group $\mathrm{C}$ showed good vision at the end of 15-day treatment.

Blindness is a customary sequel of many diseases/ conditions like listeriosis, infectious bovine keratoconjuctivitis, etc occurring in cattle, but often goes unnoticed and uncared. Even after the animal recovers from affected cause, blindness still persists and indirectly affects the animal's integral merit. In some cases blindness occurs without any specific cause and this also post a check on treatment for blindness. But it is needed to be cared of ethically considering the animal's welfare, as well as its productivity.

Hence general treatment using allopathic supplement of vitamins and ethno-medicinal formulation are comparatively studied.

Since blindness due to vitamin A deficiency is the most prevalent [1], one group were given vitamin supplements. 
Therapeutic action of the ingredients used in this study is

- Datura inoxia have been used to obtain visions [2].

- Sweet flag was one used for treating eye diseases, and thus its generic name, Acorus is derived from the Greek word akore, meaning 'without pupil'. The specific name comes from the Arabic kalon, and means 'reed', referring to the iris or flag-like foliage [3].

- Allium sativum, garlic, was supposed to improve eyesight. When cattle lost their vision, farmers hung roots of it about their necks [4].

- Common salt, sodium chloride, its importance in cattle diet is recognized for thousands of years. It provides palatability and the cattle will voluntarily consume far more than enough [5].

- Cow butter has vitamin A varying between 200-2000 microgram/ 100gram. Only cow's milk contains 6.0 microgram carotenes which are converted to vitamin $\mathrm{A}$ in the body [6].

The above ingredients were combined in a specific proportion and employed for treating the blindness. Eventually the successful refinement is recorded.

\section{ACKNOWLEDGMENT}

We, the authors, thankfully acknowledge the support of ethno-medicinal practitioners, cattle owners and field veterinarians.

\section{Conflict of interest}

The author(s) declare(s) that there is no conflict of interest.

\section{REFERENCES}

1. Audrey $\mathrm{H}$ Ensminger, MEEnsminger, James $\mathrm{E}$ Konlande, John R K Robson. Foods and nutrition encyclopedia, Edn 2, CRC press, LLC. 1994; (1): 217.

2. Elaine Elisabetsky, Nina L Etkin. Ethnopharmacology, Vol II, Eolss publishers, UK. $2009 ; 156$.

3. DeBaggio T, Tucker AO. The Encyclopedia of Herbs: A Comprehensive Reference to Herbs of Flavor and Fragrance. Timber Press; 2009 Sep 1.

4. Jerry Mack Johnson. Old-Time Country Wisdom \& Lore: 1000s of Traditional Skills for Simple Living, Voyageur press; 2011: 261.

5. Miller WJ. Dairy Cattle Feeding and Nutrition, Academic press, USA; 1979: 121

6. Mahindru SN. Milk and milk products, APH publishing, New Delhi; 2009: 58. 